\title{
New insights into congenital diaphragmatic hernia - a surgeon's introduction to CDH animal models
}

\author{
Priscilla Pui Lam Chiu* \\ Division of Pediatric General and Thoracic Surgery, Department of Surgery, The Hospital for Sick Children, University of Toronto, Toronto, ON, Canada
}

Edited by:

Juan A. Tovar, Hospital Universitario

La Paz, Spain

Reviewed by:

Francesco Morini, Ospedale

Pediatrico Bambino Gesù, Italy

Hiroyuki Koga, Juntendo University

School of Medicine, Japan

${ }^{*}$ Correspondence:

Priscilla Pui Lam Chiu, Division of

Pediatric General and Thoracic

Surgery, Department of Surgery, The

Hospital for Sick Children, University

of Toronto, 555 University Avenue,

Room 1518, Toronto, ON M5G 1 X8,

Canada

e-mail: priscilla.chiu@sickkids.ca
In recent decades, new research into the developmental defects and pathophysiological basis of congenital diaphragmatic hernia $(\mathrm{CDH})$ has revealed opportunities for the development of innovative therapies. Importantly, the use of animal models to represent this anomaly in the laboratory has resulted in the discovery of many important genetic, epigenetic, and other molecular contributors to this condition. In this review, the most commonly used and newly devised animal models of $\mathrm{CDH}$ are presented to familiarize the reader with the latest innovations in the basic sciences.

Keywords: congenital diaphragmatic hernia, pulmonary hypoplasia, genetic models, teratogen, fetal lamb, fetal surgery, fetal tracheal occlusion

\section{INTRODUCTION}

Pediatric surgeons continue to face the challenge of treating a variety of congenital anomalies and neonatal disorders for which the etiology and pathophysiology are poorly understood and understudied. In addition to the fact that many of these defects are rare in overall incidence and lack a known genetic cause, there has been a general dearth of biological or animal models to specifically study the conditions that result from developmental failures. However, for congenital diaphragmatic hernia $(\mathrm{CDH})$, there has been much research effort and productivity. Over the past four decades, an increasing number of animal models - small and large animal, teratogenic, and experimental, have been employed to give scientists and clinicians the basis toward a better scientific understanding of this condition, we treat surgically. In this paper, I will provide a brief and updated summary of the currently available animal models for $\mathrm{CDH}$, the history of their use, discoveries made using these models and highlight new insights for future studies.

\section{CONGENITAL DIAPHRAGMATIC HERNIA}

Congenital diaphragmatic hernia is a rare birth defect affecting 1 in 2500 live births (1). Surgeons have been intimately involved in the treatment of this defect for over 60 years since Gross first reported his repair of a $\mathrm{CDH}$ neonate (2). While $\mathrm{CDH}$ overall mortality has decreased to $20 \%$ or less in the last decade $(3,4)$ compared to over $50 \%$ mortality of the previous decades owing largely to improvements in postnatal resuscitation and lung-preservation management $(5,6)$, mortality remains a significant outcome and long-term morbidity for survivors is common $(3,7,8)$. Unequivocally, the greatest challenge for the past six decades in the management of $\mathrm{CDH}$ patients has been the inability to post-natally reverse the severity of lung hypoplasia affecting both lungs and not just on the side ipsilateral to the hernia (9). The cardiorespiratory morbidity for $\mathrm{CDH}$ survivors can persist well beyond the neonatal period. Fortunately, in the past three decades this anomaly has garnered great prominence and attention from both basic science and clinical research communities resulting in new knowledge about this condition and the promise of clinical interventions aimed at correcting the lethal lung defects.

To perform this research, scientists have utilized rodent models (teratogenic and genetic) and the experimental large animal (fetal lamb) model. These two models have been functionally although not exclusively complementary in their research applications. The teratogenic rodent model has a long history and is widely used to determine the fundamental developmental and physiological defects of $\mathrm{CDH}$, specifically in dissecting the molecular and cellular features of $\mathrm{CDH}$ in order to understand their effects on diaphragm, lung, and vascular development (10). In parallel, the experimental fetal lamb model pioneered by de Lorimier et al. (11) in San Francisco and Haller et al. (12) in Baltimore has been adopted for studies of the $\mathrm{CDH}$-affected lung and the surgical interventions to reverse these defects. Most importantly, its use has been instrumental for the advances in the field of fetal surgery including fetal tracheal occlusion for the prenatal intervention of high-risk $\mathrm{CDH}$ currently under clinical trial (13). Undoubtedly, this congenital anomaly has become the "poster child" for the bench-to-bedside crosstalk between basic and clinical researchers so that new discoveries can be translated into clinical interventions to improve $\mathrm{CDH}$ patient outcomes. With the pace of this research accelerating, the clinical benefits stemming from the research performed using these $\mathrm{CDH}$ animal models will continue to be realized in the near future. 


\section{TERATOGENIC MODEL FOR CDH}

The most commonly used teratogenic model for $\mathrm{CDH}$ is the nitrofen model. Nitrofen (also known as NIP in Japan and niclofen in Canada), is 2,4-dichloro-1-(4-nitrophenoxy)benzene, a Protox-inhibiting herbicide of the diphenyl ether class. Its use has been banned in Europe, Canada, and the United States since the mid-1990s for its documented carcinogenic effects on rodents (liver and pancreatic adenocarcinomas) and is considered a Group $2 \mathrm{~B}$ class carcinogen (possibly carcinogenic to humans) $(14,15)$. It was identified as a teratogen in studies with rodent dams where pups were born cyanotic, exhibited respiratory distress, and died shortly after birth (16). The teratogenic effect of nitrofen is exerted mainly during the critical period of organogenesis (17). As a result, timed matings are required for the model and the herbicide is orally fed at a dose of $50 \mathrm{mg} / \mathrm{kg} /$ day or higher between E8-9 for mice and E8-12 for rats (correlating with human gestational age of 4-6 weeks), producing hypoplastic lungs and a spectrum of diaphragmatic defects in the pups similar to the human disorder $(18,19)$. Interestingly, the timing of teratogen exposure also affects $\mathrm{CDH}$ laterality, as earlier exposure increases the frequency of leftsided defects whereas administration later in gestation (E10-12) increases right-sided incidence (10). Not all of the pups are affected with $\mathrm{CDH}$ and, unlike the human disease, the litter will also have pups affected by other developmental abnormalities of the kidneys, heart, and skeleton $(19,20)$.

Initial studies using the nitrofen model were particularly fruitful in debunking embryological myths surrounding $\mathrm{CDH}$ pathogenesis, with the most detailed studies coming from John Greer's group. While it had been speculated that $\mathrm{CDH}$ development resulted from the failure of the pleuroperitoneal canal to close in mid-gestation thereby causing the diaphragmatic sequelae, the nitrofen model revealed that $\mathrm{CDH}$ occurs early (17) from developmental abnormalities of the pleuropulmonary fold (PPF), specifically it is a muscular mesenchymal component $(21,22)$. Whether this finding applied to the human disease or specifically to this model of $\mathrm{CDH}$ pathogenesis was not proven. However, given that genetic models of $\mathrm{CDH}$, such as the mouse models disrupting the expression of the Wilm's Tumor 1 (WT1 $1^{-1-}$ ) or the chicken ovalbumin upstream promoter-transcription factor II (COUP-TFII) gene (see the section below) showed similar changes in PPF morphology, there appears to be good evidence that similar changes underlie the human defect.

With access to the earliest stages of $\mathrm{CDH}$ pathogenesis in this teratogenic model, multiple developmental pathways have been implicated as the mechanism(s) driving nitrofen-induced CDH. Initial observations suggested that nitrofen was thyromimetic and exerted its teratogenic effects by disrupting the maternal-fetal thyroid hormone pathway through suppression of maternal TSH levels (23). However, subsequent studies showed direct delivery of the nitrofen compound rather than maternally produced active metabolites into the fetus through the maternal-fetal circulation, indicating the potential for direct effects of nitrofen on fetal diaphragm and lung development (24). More recent studies have also implicated the retinoic acid pathway as significantly altered by fetal nitrofen exposure (see the section below). Additionally, nitrofen may also exert epigenetic effects in lung development as miR-200b expression is decreased in nitrofen-induced lung hypoplasia (25). The extent of the molecular and developmental pathways implicated as mechanisms in nitrofen-induced $\mathrm{CDH}$ is beyond the scope of this review but is well summarized in a recent publication (26). Finally, the teratogenic effects of nitrofen do not appear to be limited to airway and diaphragm morphogenesis, as changes in pulmonary lymphatics (27), innervation (28-30), and the mesenchyme itself (31) were also observed in the nitrofen model. By interrogating the underlying molecular and genetic pathways occurring at the earliest stages of nitrofen-induced $\mathrm{CDH}$ pathogenesis, investigators are now devising therapies to minimize the severity of pulmonary hypoplasia and validating those therapies using this pre-clinical model (32-34).

For completeness, it should be noted that other chemicals have also been identified as teratogens causing $\mathrm{CDH}$. One is 4-biphenyl carboxylic acid (BPCA), a metabolite of $\mathrm{AH} 23848$, a thromboxane- $\mathrm{A}_{2}$ receptor antagonist originally developed to inhibit platelet aggregation (35). Bisdiamine, or $N, N^{\prime}$-octamethylenebis (dichloroacetamide), is a spermatogenesis inhibitor whose teratogenic effects in addition to $\mathrm{CDH}$ include cardiovascular anomalies (36). SB-210661, a benzofuranyl urea derivative developed by GlaxoSmithKline, is a potent 5-lipoxygenase inhibitor developed as an anti-inflammatory agent for coronary artery disease. All three compounds were found to cause $\mathrm{CDH}$ in rats similar to nitrofen (37). Importantly, these agents, including nitrofen (38), inhibit retinal dehydrogenase-2 (RALDH-2), a key enzyme for the production of retinoic acid, suggesting that disruption of the retinoid signaling pathway (including vitamin A deficiency) contributes to $\mathrm{CDH}$ pathogenesis. Conversely, augmentation of vitamin A levels may also reverse this defect (39), leading to the tantalizing possibility that the earliest interventions to prevent $\mathrm{CDH}$-related defects may be as simple as vitamin supplementation. To further dissect the role of the retinoid acid pathway in $\mathrm{CDH}$ pathogenesis, genetic models were the next logical tools for these investigations.

\section{GENETIC MODELS OF CDH}

Whether by intention or serendipity, genetic models of $\mathrm{CDH}$ became available as molecular techniques for gene silencing or over-expression grew into wider application. While the majority of human $\mathrm{CDH}$ cases are not associated with known genetic defects [I will refer the reader to reference (40) for an excellent review of the genetic factors in human $\mathrm{CDH}]$, multiple genetic models have been associated with $\mathrm{CDH}$ as part of their phenotype. Although the specific effect of retinoid pathway inhibition on $\mathrm{CDH}$ development was not revealed until recently, the disruption of both retinoic acid receptor $\alpha$ and $\beta$ genes, thus disrupting the entire retinoic acid signaling pathway, resulted in $\mathrm{CDH}(41)$ and confirmed previous reports implicating the role of vitamin A deficiency in CDH development $(42,43)$. Not surprisingly, disruption of other genes involved in the retinoic acid pathway has also resulted in $\mathrm{CDH}$ amongst other defects in organogenesis $(44,45)$.

Genes encoding hormone receptors overlapping with the retinoid pathway have also yielded the $\mathrm{CDH}$ phenotype when their expression has been disrupted. The COUP-TFII gene, also known as NR2F2, is a transcriptional protein belonging to the steroid/thyroid hormone receptor superfamily whose expression 
is regulated by retinoids and, in turn, include among its functions the regulation of gene transcription by modulation of retinoic acid receptor heterodimerization $(46,47)$. Of note, the COUPTFII gene is on chromosome $15 \mathrm{q} 26$ - a region recurrently deleted in $\mathrm{CDH}$ patients $(48,49)$, thus making it the candidate gene. Mice with tissue-specific ablation of this gene also exhibit $\mathrm{CDH}$ defects (50).

The role of genes less obviously associated with human $\mathrm{CDH}$ has also been revealed through genetic models. Mutations of the Wilm's Tumor 1 gene, WT1, in two cases of human CDHassociated with Denys-Drash syndrome have been reported (40). Abrogated expression of WT1 in mice was found to be associated with fetal CDH development (51) with its effects appearing to be exerted through the common retinoid pathway (52). In some cases, diaphragmatic defects resulting from genetic defects bear less resemblance to the classic human condition. Genes that encode the SLIT family of proteins involved in a diverse array of neuronal cells also appear to affect diaphragm development although slightly different from the classic Bochdalek hernias when their expression is disrupted. Mice harboring the disrupted slit3 gene develop a central $\mathrm{CDH}$ similar to Morgagne hernias rather than Bochdalek hernias (53). Friend of GATA 2 (FOG2) encodes a zinc finger protein (54) that primarily interacts with GATA4, a member of a family of DNA-binding proteins so named because they recognize the GATA motif in the promoter regions of many genes (55). FOG2-GATA4 interaction modulates gene expression during many developmental processes including heart morphogenesis. Mice harboring a fog 2 mutation were found to have diaphragmatic defects in the posterior and peripheral aspects (56) while mice carrying a single copy of the mutated gata4 developed heart, lung, and diaphragm defects (57). Interestingly, the chromosomal regions where the human FOG2 and GATA4 genes are located have been found to be deleted in some $\mathrm{CDH}$ patients (40).

\section{EXPERIMENTAL MODEL FOR CDH}

While the $\mathrm{CDH}$ rodent models are scaled and optimized to uncover early developmental and genetic derangements contributing to $\mathrm{CDH}$, large animal models for $\mathrm{CDH}$ are scaled for life-sized interventions of the affected lung or diaphragm for direct translation to the clinical domain. As large animal models of $\mathrm{CDH}$ require diaphragmatic defects to be created during early stages of fetal development, this model cannot be used to study the earliest origins of the $\mathrm{CDH}$ diaphragmatic defect that is better served by the rodent models. The fetal lamb is the most commonly used experimental model but some researchers have also used rabbits for similar studies (58).

One of the pivotal reasons for choosing the fetal lamb model for $\mathrm{CDH}$ was that there was already a large body of literature on fetal lamb pulmonary physiology prior to its adoption as a $\mathrm{CDH}$ model. With this background, the fetal lamb model for $\mathrm{CDH}$ has aided the study of ventilator-related lung damage observed in $\mathrm{CDH}$ and the development of fetal interventions aimed at arresting or reversing $\mathrm{CDH}$-associated pulmonary hypoplasia. As the fetal lamb model was more expensive and time-consuming for $\mathrm{CDH}$ research compared to rodent models, most investigations focused exclusively on defining the pulmonary effects of $\mathrm{CDH}$ or fetal ventilation strategies (59-61). To create this model (and technical details varied between laboratories), the fetal lamb is delivered out of the ewe between 80 and up to 110 days' gestation with the gravid ewe under full general anesthesia. The technique requires positioning the hysterotomy directly over the fetal thorax by palpation of the uterus in order to minimize the size of the uterine incision. The chest of the fetal lamb is delivered out of the wound for the incision to be made in the 11th intercostal space, thus exposing the fetal diaphragm. The diaphragm is incised and abdominal viscera are introduced into the thorax. The thorax is closed and the hysterotomy repaired. Planned delivery of the treated fetal lambs is required as ventilatory support immediately post-delivery is necessary. In initial studies where fetal interventions required repeat open fetal surgery, the overall survival of the fetal lambs was disappointingly low as the primary procedure to create the $\mathrm{CDH}$ was performed earlier in gestation and repeat hysterotomy created challenges including pre-term labor and stillbirths $(62,63)$. However, the hard lessons learned from these studies brought about more ingenious ways to circumvent these obstacles, including the application of tocolytic protocols and the eventual use of minimal access approaches for fetal repair.

Twenty-five years after he first started his laboratory studies in the fetal lamb model for $\mathrm{CDH}$, the first randomized controlled trial of fetal tracheal occlusion for the treatment of high-risk $\mathrm{CDH}$ was reported by Harrison et al. in 2003 (64). While the outcome of fetal tracheal occlusion for high-risk CDH infants did not appear significantly different from the conventionally treated cohort, the trial represented the culmination of the many years of laboratory-based research, scientific interactions, and optimization of techniques using the experimental fetal lamb model in pre-clinical studies $(60,65-67)$. Consequently, clinicians treating other congenital anomalies with open fetal surgery now have the innovative techniques and clinical tools to support their procedures (68). The fetal lamb model is now widely used as a pipeline for the refinement of fetoscopic and open fetal surgical techniques for trainees (69).

\section{CONCLUSION}

Animal models for $\mathrm{CDH}$ have generated vast troves of data in diverse areas of science and medicine. Rodent and fetal lamb models for $\mathrm{CDH}$ have encouraged crosstalk between geneticists, developmental biologists, and clinicians to discover new knowledge and create new treatment targets for fetal interventions, particularly in arresting or reversing the devastating pulmonary sequelae of $\mathrm{CDH}$. The field of fetal surgery owes a debt of thanks to $\mathrm{CDH}$ disease and the research teams who first imagined fetal surgery as a treatment option. The past use of these animal models has yielded exciting results, spawning clinical trials and novel therapies for $\mathrm{CDH}$. There is hope and excitement for other congenital anomalies that similar use of animal models will also bring such fruitful results for our patients.

\section{REFERENCES}

1. Langham MR Jr, Kays DW, Ledbetter DJ, Frentzen B, Sanford LL, Richards DS Congenital diaphragmatic hernia. Epidemiology and outcome. Clin Perinatol (1996) 23:671-88.

2. Gross R. Congenital hernia of the diaphragm. Am J Dis Child (1946) 71:579-92.

3. Chiu PP, Sauer C, Mihailovic A, Adatia I, Bohn D, Coates AL, et al. The price of success in the management of congenital diaphragmatic hernia: is improved 
survival accompanied by an increase in long-term morbidity? J Pediatr Surg (2006) 41:888-92. doi:10.1016/j.jpedsurg.2006.01.026

4. Downard CD, Jaksic T, Garza JJ, Dzakovic A, Nemes L, Jennings RW, et al. Analysis of an improved survival rate for congenital diaphragmatic hernia. J Pediatr Surg (2003) 38:729-32. doi:10.1016/jpsu.2003.50194

5. Azarow K, Messineo A, Pearl R, Filler R, Barker G, Bohn D. Congenital diaphragmatic hernia - a tale of two cities: the Toronto experience. J Pediatr Surg (1997) 32:395-400. doi:10.1016/S0022-3468(97)90589-3

6. Wilson JM, Lund DP, Lillehei CW, Vacanti JP. Congenital diaphragmatic hernia - a tale of two cities: the Boston experience. J Pediatr Surg (1997) 32:401-5. doi:10.1016/S0022-3468(97)90590-X

7. Muratore C, Utter S, Jaksic T, Lund D, Wilson J. Nutritional morbidity in survivors of congenital diaphragmatic hernia. J Pediatr Surg (2001) 36:1171-6. doi:10.1053/jpsu.2001.20031

8. Muratore CS, Kharasch V, Lund DP, Sheils C, Friedman S, Brown C, et al. Pulmonary morbidity in 100 survivors of congenital diaphragmatic hernia monitored in a multidisciplinary clinic. J Pediatr Surg (2001) 36:133-40. doi:10.1053/jpsu.2001.25746

9. Bohn D. Congenital diaphragmatic hernia. Am J Respir Crit Care Med (2002) 166:911-5. doi:10.1164/rccm.200204-304CC

10. Greer JJ. Current concepts on the pathogenesis and etiology of congenital diaphragmatic hernia. Respir Physiol Neurobiol (2013) 189:232-40. doi:10.1016/ j.resp.2013.04.015

11. DeLorimier A, Tierney D, Parker H, DeLorimier AA, Tierney DF, Parker HR. Hypoplastic lungs in fetal lambs with surgically produced congenital diaphragmatic hernia. Surgery (1967) 62:12-7.

12. Haller J Jr, Signer R, Golladay E, Inon AE, Harrington DP, Shermeta DW. Pulmonary and ductal hemodynamics in studies of simulated diaphragmatic hernia of fetal and newborn lambs. J Pediatr Surg (1976) 11:675-80. doi:10.1016/00223468(76)90089-0

13. Dekoninck P, Gratacos E, Van Mieghem T, Richter J, Lewi P, Ancel AM, et al. Results of fetal endoscopic tracheal occlusion for congenital diaphragmatic hernia and the set up of the randomized controlled TOTAL trial. Early Hum Dev (2011) 87:619-24. doi:10.1016/j.earlhumdev.2011.08.001

14. Lunn R, editor. Report on Carcinogens, 12 th ed. U. S. Department of Health and Human Services, Public Health Service, National Toxicology Program, DIANE Publishing (2011), p. 296-7. Available from: http://ntp.niehs.nih.gov/?objectid= 035E57E7-BDD9-2D9B-AFB9D1CADC8D09C1

15. World Health Organization. WHO/FAO Data Sheets on Pesticides - No. 84, Nitrofen. Food and Agriculture Organization of the United Nations (1996). Available from: http://www.inchem.org/documents/pds/pds/pest84_e.htm

16. Manson JM. Mechanism of nitrofen teratogenesis. Environ Health Perspect (1986) 70:137-47. doi:10.1289/ehp.8670137

17. Kluth D, Tenbrinck R, von Ekesparre M, Kangah R, Reich P, Brandsma A, et al. The natural history of congenital diaphragmatic hernia and pulmonary hypoplasia in the embryo. J Pediatr Surg (1993) 28:456-62. doi:10.1016/00223468(93)90248-J

18. Stone LC, Manson JM. Effects of the herbicide 2,4-dichlorophenyl-pnitrophenyl ether (nitrofen) on fetal lung development in rats. Toxicol Appl Pharmacol (1981) 20:195-207. doi:10.1016/0300-483X(81)90051-2

19. Costlow RD, Manson JM. The heart and diaphragm: target organs in the neonatal death induced by nitrofen (2,4-dichlorophenyl-p-nitrophenyl ether). Toxicology (1981) 20:209-27. doi:10.1016/0300-483X(81)90052-4

20. Greer JJ, Babiuk RP, Thebaud B. Etiology of congenital diaphragmatic hernia: the retinoid hypothesis. Pediatr Res (2003) 53:726-30. doi:10.1203/01.PDR. 0000062660.12769.E6

21. Allan D, Greer J. Pathogenesis of nitrofen-induced congenital diaphragmatic hernia in fetal rats. J Appl Physiol (1997) 83:338-47.

22. Babiuk R, Greer J. Diaphragm defects occur in a $\mathrm{CDH}$ hernia model independently of myogenesis and lung formation. Am J Physiol Lung Cell Mol Physiol (2002) 283:L1310-4. doi:10.1152/ajplung.00257.2002

23. Manson J, Brown T, Baldwin D. Teratogenicity of nitrofen (2,4-dichloro-4'nitrodiphenyl ether) and its effects on thyroid function in the rat. Toxicol Appl Pharmacol (1984) 73:323-5. doi:10.1016/0041-008X(84)90338-7

24. Brown T, Manson J. Further characterization of the distribution and metabolism of nitrofen in the pregnant rat. Teratology (1986) 34:129-39. doi:10.1002/ tera. 1420340202

25. Pereira Terra P, Deden AC, Zhu F, Barb I, Jorge Correia P, Richard K. MicroRNA miR-200b rescues abnormal branching morphogenesis of nitrofen-induced hypoplastic lung explants. Canadian Association of Pediatric Surgeons 45th Annual Meeting. Charlottetown, PE: Canadian Association of Pediatric Surgeons (2013).

26. Greer JJ, Allan DW, Babiuk RP, Lemke RP. Recent advances in understanding the pathogenesis of nitrofen-induced congenital diaphragmatic hernia. Pediatr Pulmonol (2000) 29:394-9. doi:10.1002/(SICI) 1099-0496(200005)29:5<394::AIDPPUL9>3.0.CO;2-2

27. Shue E, Wu J, Schecter S, Miniati D. Aberrant pulmonary lymphatic development in the nitrofen mouse model of congenital diaphragmatic hernia. J Pediatr Surg (2013) 48:1198-204. doi:10.1016/j.jpedsurg.2013.03.013

28. Martínez L, Aras-López R, Lancha S, Vallejo-Cremades MT, Pederiva F, XiaoMei $\mathrm{L}$, et al. Abnormal development of the enteric nervous system in rat embryos and fetuses with congenital diaphragmatic hernia. Pediatr Surg Int (2011) 27:165-73. doi:10.1007/s00383-010-2788-x

29. Lath NR, Galambos C, Rocha AB, Malek M, Gittes GK, Potoka DA. Defective pulmonary innervation and autonomic imbalance in congenital diaphragmatic hernia. Am J Physiol Lung Cell Mol Physiol (2012) 302:L390-8. doi:10.1152/ ajplung.00275.2011

30. Pederiva F, Lopez R, Rodriguez J, Martinez L, Tovar J. Bronchopulmonary innervation defects in infants and rats with congenital diaphragmatic hernia. J Pediatr Surg (2010) 45:360-5. doi:10.1016/j.jpedsurg.2009.10.076

31. van Loenhout RB, Tseu I, Fox EK, Huang Z, Tibboel D, Post M, et al. The pulmonary mesenchymal tissue layer is defective in an in vitro recombinant model of nitrofen-induced lung hypoplasia. Am J Pathol (2012) 180:48-60. doi:10.1016/j.ajpath.2011.09.032

32. Chang YT, Ringman Uggla A, Osterholm C, Tran PK, Eklöf AC, Lengquist M, et al. Antenatal imatinib treatment reduces pulmonary vascular remodeling in a rat model of congenital diaphragmatic hernia. Am J Physiol Lung Cell Mol Physiol (2012) 302:L1159-66. doi:10.1152/ajplung.00325.2010

33. Luong C, Rey-Perra J, Vadivel A, Gilmour G, Sauve Y, Koonen D, et al. Antenatal sildenafil treatment attenuates pulmonary hypertension in experimental congenital diaphragmatic hernia. Circulation (2011) 123:2120-31. doi:10.1161/ CIRCULATIONAHA.108.845909

34. Nogueira-Silva C, Carvalho-Dias E, Piairo P, Nunes S, Baptista MJ, Moura RS, et al. Local fetal lung renin-angiotensin system as a target to treat congenital diaphragmatic hernia. Mol Med (2012) 18:231-43. doi:10.2119/molmed.2011. 00210

35. Sutherland M, Parkinson M, Hallett P. Teratogenicity of three substituted 4biphenyls in the rat as a result of the chemical breakdown and possible metabolism of a thromboxane A2-receptor blocker. Teratology (1989) 39:537-45. doi:10.1002/tera.1420390604

36. Kise K, Nakagawa M, Okamoto N, Hanato T, Watanabe N, Nishijima S, et al. Teratogenic effects of bis-diamine on the developing cardiac conduction system. Birth Defects Res A Clin Mol Teratol (2005) 73:547-54. doi:10.1002/bdra. 20163

37. Mey J, Babiuk RP, Clugston RD, Zhang W, Greer JJ. Retinal dehydrogenase2 is inhibited by compounds that induce congenital diaphragmatic hernia in rodents. Am J Pathol (2003) 162:673-9. doi:10.1016/S0002-9440(10)63861-8

38. Noble BR, Babiuk RP, Clugston RD, Underhill TM, Sun H, Kawaguchi R, et al Mechanisms of action of the congenital diaphragmatic hernia-inducing teratogen nitrofen. Am J Physiol Lung Cell Mol Physiol (2007) 293:L1079-87. doi:10.1152/ajplung.00286.2007

39. Thébaud B, Tibboel D, Rambaud C, Mercier JC, Bourbon JR, Dinh-Xuan AT, et al. Vitamin A decreases the incidence and severity of nitrofen-induced congenital diaphragmatic hernia in rats. Am J Physiol Lung Cell Mol Physiol (1999) 277:L423-9.

40. Holder AM, Klaassens M, Tibboel D, de Klein A, Lee B, Scott DA. Genetic factors in congenital diaphragmatic hernia. Am J Hum Genet (2007) 80:825-45. doi: $10.1086 / 513442$

41. Mendelsohn C, Lohnes D, Décimo D, Lufkin T, LeMeur M, Chambon P, et al. Function of the retinoic acid receptors (RARs) during development (II). Multiple abnormalities at various stages of organogenesis in RAR double mutants. Development (1994) 120:2749-71.

42. Wilson J, Roth C, Warkany J. An analysis of the syndrome of malformations induced by maternal vitamin A deficiency: effects of restoration of vitamin A at various times during gestation. Am J Anat (1953) 92:189-217. doi:10.1002/aja.1000920202

43. Anderson D. Incidence of congenital diaphragmatic hernia in the young of rats bred on a diet deficient in vitamin A. Am J Dis Child (1941) 62:888-9. 
44. Pasutto F, Sticht H, Hammersen G, Gillessen-Kaesbach G, Fitzpatrick DR, Nürnberg G, et al. Mutations in STRA6 cause a broad spectrum of malformations including anophthalmia, congenital heart defects, diaphragmatic hernia, alveolar capillary dysplasia, lung hypoplasia, and mental retardation. Am J Hum Genet (2007) 80:550-60. doi:10.1086/512203

45. Kawaguchi R, Yu J, Honda J, Hu J, Whitelegge J, Ping P, et al. A membrane receptor for retinol binding protein mediates cellular uptake of vitamin A. Science (2007) 315:820-5. doi:10.1126/science.1136244

46. Qui Y, Krishnan V, Pereira S, Tsai S, Tsai M. Chicken ovalbumin upstream promoter-transcription factors and their regulation. J Steroid Biochem Mol Biol (1996) 56:81-5. doi:10.1016/0960-0760(95)00225-1

47. Tsai S, Tsai M. Chicken ovalbumin upstream promoter-transcription factors (COUP-TFs): coming of age. Endocr Rev (1997) 18:229-40. doi:10.1210/er.18. 2.229

48. Goumy C, Gouas L, Marceau G, Coste K, Veronese L, Gallot D, et al. Retinoid pathway and congenital diaphragmatic hernia: hypothesis from the analysis of chromosomal abnormalities. Fetal Diagn Ther (2010) 28:129-39. doi:10.1159/ 000313331

49. Klaassens M, van Dooren M, Eussen HJ, Douben H, den Dekker AT, Lee C, et al. Congenital diaphragmatic hernia and chromosome 15q26: determination of a candidate region by use of fluorescent in situ hybridization and arraybased comparative genomic hybridization. Am J Hum Genet (2005) 76:877-82. doi:10.1086/429842

50. You LR, Takamoto N, Yu CT, Tanaka T, Kodama T, Demayo FJ, et al. Mouse lacking COUP-TFII as an animal model of Bochdalek-type congenital diaphragmatic hernia. Proc Natl Acad Sci U S A (2005) 102:16351-6. doi:10.1073/pnas. 0507832102

51. Kreidberg J, Sariola H, Loring J, Maeda M, Pelletier J, Housman D, et al. WT-1 is required for early kidney development. Cell (1993) 74:679-91. doi:10.1016/ 0092-8674(93)90515-R

52. Clugston RD, Klattig J, Englert C, Clagett-Dame M, Martinovic J, Benachi A, et al. Teratogen-induced, dietary and genetic models of congenital diaphragmatic hernia share a common mechanism of pathogenesis. Am J Pathol (2006) 169:1541-9. doi:10.2353/ajpath.2006.060445

53. Yuan W, Rao Y, Babiuk RP, Greer JJ, Wu JY, Ornitz DM. A genetic model for a central (septum transversum) congenital diaphragmatic hernia in mice lacking Slit3. Proc Natl Acad Sci U S A (2003) 100:5217-22. doi:10.1073/pnas. 0730709100

54. Holmes M, Turner J, Fox A, Chisholm O, Crossley M, Chong B. hFOG-2, a novel zinc finger protein, binds the co-repressor mCtBP2 and modulates GATAmediated activation. J Biol Chem (1999) 274:23491-8. doi:10.1074/jbc.274.33. 23491

55. Patient R, McGhee J. The GATA family (vertebrates and invertebrates). Curr Opin Genet Dev (2002) 12:416-22. doi:10.1016/S0959-437X(02)00319-2

56. Ackerman KG, Herron BJ, Vargas SO, Huang H, Tevosian SG, Kochilas L, et al Fog2 is required for normal diaphragm and lung development in mice and humans. PLoS Genet (2005) 1:e10. doi:10.1371/journal.pgen.0010010

57. Jay PY, Bielinska M, Erlich JM, Mannisto S, Pu WT, Heikinheimo M, et al. Impaired mesenchymal cell function in Gata4 mutant mice leads to diaphragmatic hernias and primary lung defects. Dev Biol (2007) 301:602-14. doi:10. 1016/j.ydbio.2006.09.050

58. Fauza DO, Tannuri U, Ayoub AA, Capelozzi VL, Saldiva PH, Maksoud JG. Surgically produced congenital diaphragmatic hernia in fetal rabbits. J Pediatr Surg (1994) 29:882-6. doi:10.1016/0022-3468(94)90008-6

59. Glick PL, Stannard VA, Leach CL, Rossman J, Hosada Y, Morin FC, et al. Pathophysiology of congenital diaphragmatic hernia II: the fetal lamb CDH model is surfactant deficient. J Pediatr Surg (1992) 27:382-8. doi:10.1016/0022-3468(92) 90865-5
60. Bratu I, Flageole H, Laberge JM, Possmayer F, Harbottle R, Kay S, et al. Surfactant levels after reversible tracheal occlusion and prenatal steroids in experimental diaphragmatic hernia. J Pediatr Surg (2001) 36:122-7. doi:10.1053/jpsu.2001. 20027

61. Nobuhara KK, Fauza DO, DiFiore JW, Hines MH, Fackler JC, Slavin R, et al. Continuous intrapulmonary distension with perfluorocarbon accelerates neonatal (but not adult) lung growth. J Pediatr Surg (1998) 33:292-8. doi:10.1016/S0022-3468(98)90450-X

62. Adzick NS, Outwater KM, Harrison MR, Davies P, Glick PL, DeLorimier AA, et al. Correction of congenital diaphragmatic hernia in utero. IV. An early gestational fetal lamb model for pulmonary vascular morphometric analysis. JPediatr Surg (1985) 20:673-80. doi:10.1016/S0022-3468(85)80022-1

63. de Luca U, Cloutier R, Laberge JM, Fournier L, Prendt H, Major D, et al. Pulmonary barotrauma in congenital diaphragmatic hernia: experimental study in lambs. J Pediatr Surg (1987) 22:311-6. doi:10.1016/S0022-3468(87) 80231-2

64. Harrison MR, Keller RL, Hawgood SB, Kitterman JA, Sandberg PL, Farmer DL, et al. A randomized trial of fetal endoscopic tracheal occlusion for severe fetal congenital diaphragmatic hernia. N Engl J Med (2003) 349:1916-24. doi:10.1056/NEJMoa035005

65. Hashim E, Laberge J, Chen M, Quillen EJ. Reversible tracheal obstruction in the fetal sheep: effects on tracheal fluid pressure and lung growth. J Pediatr Surg (1995) 30:1172-7. doi:10.1016/0022-3468(95)90015-2

66. Flageole H, Evrard VA, Piedboeuf B, Laberge JM, Lerut TE, Deprest JA. The plug-unplug sequence: an important step to achieve type II pneumocyte maturation in the fetal lamb model. J Pediatr Surg (1998) 33:299-303. doi:10.1016/S0022-3468(98)90451-1

67. Hedrick MH, Estes JM, Sullivan KM, Bealer JF, Kitterman JA, Flake AW, et al. Plug the lung until it grows (PLUG): a new method to treat congenital diaphragmatic hernia in utero. J Pediatr Surg (1994) 29:612-7. doi:10.1016/0022-3468(94) 90724-2

68. Harrison MR, Langer JC, Adzick NS, Golbus MS, Filly RA, Anderson $\mathrm{RL}$, et al. Correction of congenital diaphragmatic hernia in utero, V. Initial clinical experience. J Pediatr Surg (1990) 25:47-55. doi:10.1016/S0022-3468(05) 80163-0

69. Jelin EB, Etemadi M, Encinas J, Schecter SC, Chapin C, Wu J, et al. Dynamic tracheal occlusion improves lung morphometrics and function in the fetal lamb model of congenital diaphragmatic hernia. J Pediatr Surg (2011) 46:1150-7. doi:10.1016/j.jpedsurg.2011.03.049

Conflict of Interest Statement: The author declares that the research was conducted in the absence of any commercial or financial relationships that could be construed as a potential conflict of interest.

Received: 08 February 2014; paper pending published: 28 February 2014; accepted: 16 April 2014; published online: 29 April 2014.

Citation: Chiu PPL (2014) New insights into congenital diaphragmatic hernia - a surgeon's introduction to $\mathrm{CDH}$ animal models. Front. Pediatr. 2:36. doi: 10.3389/fped.2014.00036

This article was submitted to Pediatric Surgery, a section of the journal Frontiers in Pediatrics.

Copyright $\odot 2014$ Chiu. This is an open-access article distributed under the terms of the Creative Commons Attribution License (CC BY). The use, distribution or reproduction in other forums is permitted, provided the original author(s) or licensor are credited and that the original publication in this journal is cited, in accordance with accepted academic practice. No use, distribution or reproduction is permitted which does not comply with these terms. 